\title{
The Theory and Practice of Combining Local Art Resources with College Ideological and Political Classrooms
}

\author{
Li Ren \\ Guangxi Academy of Art, Marxism College 530022
}

Keywords: Ideological and political lessons; art resources; local culture; teaching reform

\begin{abstract}
Local art resources is an art work that shows the development of local society in a local style. It represents the regional cultural characteristics and represents the process of localization of Marxism in China. It is suitable for the introduction of ideological and political classrooms in colleges and universities. In practice, under the leadership of local art academies, the local red cultural resources should first be transformed into art resources-assisted teaching, and then local art resources should be extended to the ideological and political classrooms of national universities through cross-regional exchanges and cooperation.

In the teaching of ideological and political theory courses (hereinafter referred to as ideological and political courses) in colleges and universities, the integration of artistic resources as a method of in-depth theoretical explanation and active classroom atmosphere has increasingly become an important means for contemporary colleges and universities to improve the quality of ideological and political classroom teaching. The availability of local art resources should be paid attention to in the practice of integrating art resources into the teaching of ideological and political courses. How to develop and apply the outstanding characteristics of local art resources is of great significance to further deepen the integration of artistic resources into the reform of ideological and political education in colleges and universities.
\end{abstract}

\section{Interpretation of local art resources and its research situation}

The word "resource" corresponds to the English Resource, which consists of the prefix "Re" and the stem "Source": the prefix "Re" stands for "re-, re-", and the "Source" is derived from the Latin verb. The old French term "Sourse" (Surse, water source) evolved from "Surgere" (rise, from) represents the source of an element. Look the word "resource" up,it corresponds to the Chinese definition of "resources", the "source" of "resources" is the meaning of "source,", and "capital" from the source of words, "Shuo Wen" is interpreted as "goods", which corresponds to "property and goods" represented by "bei". Therefore, the word "capital" itself represents a kind of material existence with economic and social attributes. Comparing the words "Resource" and "Zi Yuan", we can find that the "Zi Yuan" in Chinese have more economic and social material meanings than the English "Resources". In other words, the English "Resource" is more biased towards the explanation of "source", and the word "resource" originally contains the meaning of social material. In summary, the basic meaning of the term "resources" is the source of certain material elements with social attributes, which determines that "resources" have both material and social attributes.

The use of "art" and "resources" in China's academic circles has long been seen in the mid-1990s. It is worth noting that the term "art resources" is used in addition to the source of artistic works as a material existence. It is closely related to social activities such as tourism, internet and business. Therefore, the understanding and definition of "art resources" refers broadly to the source of the material existence of art works, but more specifically, the existence of such material must have a social representation, that is, with the economy, culture and even politics and so on art works related to social activities.

Relative to the broad concept of "society", "place" points to a specific region and place in China, "place" mainly refers to administrative regions such as provinces, municipalities, autonomous regions, etc., such as the term "Tibet place". It can represent specific areas that are opposite to the 
country, such as "local culture". In fact, the concept of "local art" was gradually formed in the 1980s. Earlier, Mei Jianying's "Questions about Local Art Styles--Speaking about the Characteristics of Shandong Zibo Color Porcelain", "Local Art Style" "Defined as "the artistic style and characteristics of a certain region, after a long period of artistic practice and production, showing a mature and unique artistic style" 1 , pointed out the representative characteristics of "local art" in regional culture. In recent years, with the continuous advancement of globalization, under the strong influence of foreign culture, issues concerning the inheritance and development of native culture have been paid more and more attention. As a result, research on the concepts of "local" and "local art" has gradually increase, representative ones such as Huang Yongjian's research on "localization" and "locality", he thinks that "local" is not only a geographical concept, but also contains more cultural, political, and economic significance ${ }^{[3]}$, prominent the social attributes of the "local" concept. In view of the previous research on "local" and "local art", it is considered that "local art resources" not only has the geographical representation of "local art", but also further shows the social attributes of "local", in other words, " "local art resources" refers to art works that express the cultural, political, and economic aspects of the region in a local art style.

At present, in the research on the integration of art resources into the ideological and political teaching in colleges and universities, there are mainly two directions of research trends that are the focus of attention. First, the combination of resource utilization in art colleges and the study of ideological and political education in colleges and universities. Since art colleges themselves have considerable artistic resources, they have inherent advantages in the construction of artistic talents, the construction of art platforms and the development of artistic practice activities. Therefore, they first turned their attention to artistic resources in the ideological and political the application problems in the teaching of the class: For example, Xu Hui and He Yuwen first pointed out that the artistic resources have rich appeal and attraction, and has a significant impact in improving the effectiveness of ideological and political education in colleges and universities in the article "Relying on the artistic resources to improve the effectiveness of the teaching of ideological and political courses"1 ${ }^{2]}$.

Secondly, the reasonable study on the integration of art resources integrated into ideological and political teaching in colleges and universities. Ideological and political education is a vital and indispensable part of education.

The ideological and political teaching is a vital and indispensable part of university education. It is related with the cultivation of the ideology and morality, patriotic sentiment and the national consciousness of college students and postgraduates. It is also the highlight of the progress of socialist education under the leadership of the party and the state. This requires that the teaching method of ideological and political course in colleges should not only be diversified, but also rationalized. Therefore, before using art resources, it is necessary to discuss whether it can be introduced into the ideological and political courses of colleges and universities. This kind of investigation on the availability of art resources has received some attention in the preceding research, and most scholars start from the essential attributes to explore whether the two have something in common. The representative is Wu Xiaochun's suggestion of "ideology". According to the basic theory of Marxist philosophy, he points out that ideology is the essential attribute of being. This is in line with the ideological and constitutional course of the ideological education itself. The combination of the two is available in theory.

From the above two research directions, the result of discussion on the necessity and feasibility of integrating art resources into the ideological and political courses of colleges and universities has already appeared. This shows that the positive effect of art resources on the teaching of ideological and political course has been obtained to a certain extent. Attention. However, in practical, what kind of artistic resources are more suitable for the teaching of ideological and political teachers, and how to use art resources in a more rational way in the teaching process are topics that need further research. 


\section{Feasibility of Integrating Local Art Resources into College Ideological and Political Education}

In view of the question of how to choose the artistic resources that is to be introduced to the ideological and political courses, it is considered that local art resources, as an important part of local culture, can not only express the local social form and cultural characteristics, but also spread the locality of Marxism in China. The specific manifestation of influence is of high utilization value for ideological and political teaching.

In terms of feasibility, first of all, the local art resources show the creation of people in the regional environment and represent the development of regional culture. Art reflects real life in its unique form, which is a portrayal of social, historical and cultural development. At the same time, it is a human spiritual creation, being the connection between man and society. Therefore, as a carrier of the relationship between reality and spirit, and between human and society, art works can not only show the local historical development and ideology at that time, but also show the rich creativity of people in history and society. Therefore, local art resources reflect the influence of local society, environment and culture on art creators, symbolizing the interaction between local people and society. It is a vivid display of local cultural characteristics in the form of art and an important part of local culture. Integrating local art resources into the ideological and political classrooms of colleges enables students not only to learn local culture, but also to feel the connection between people and society more deeply under the influence of local art. The regional artistic education motivates students to study Marxist view of history and society.

Second, local art resources can show the circulation and influence of Marxism in China. Specifically, art resources have abundant forms of presentation, such as music, painting, sculpture, and architecture.

It stands for pouring into the material or immaterial objects the creator's perception of the situation of local society at that time, expressing the creation of thinking in the form of works. Therefore, the existence of art resources is diverse and involves all aspects of real life. From this point of view, among the local art resources, it is inevitable to find representative work that reflects the combination of Marxist theory and different social backgrounds and folk customs in China. For example, such as large-scale oil paintings by the famous painter Xu Beihong in Guangxi. "Guangxi Sanjie" is a painstaking work he finished in the winter of 1936 and the first few months of 1937. He showed his praise for the spirit of the three wars of the Gui Lijun, Li Zongren, Bai Chongxi and Huang Shaozhen. The works can not only vividly display the historical features of the anti-Japanese war in Guangxi, but also illustrate the special national conditions of anti-imperialist and anti-feudalism in the stage of China's new-democratic revolution, and reflect the background of the formation of the "United Front" revolutionary program under the leadership of the party. Therefore, among the treasure houses of regional art resources, there are many excellent works of art that vividly display the spread of Marxism in China. They are the embodiment of Marxism in China. The introduction of these resources as a teaching material into the ideological and political classrooms will enable them to realize the ethical, social and cultural changes and developments in China under the influence of Marxism. For ideological and political teachers, taking specific artistic resources as an example is more conducive to the theory and practice of classroom explanation, and to improve the context and interest of the teaching process.

At present, under the guidance of the party and the state, the development and utilization of local red cultural resources throughout the country has been quite extensive. For example, red cultural bases represented by revolutionary sites, war memorials, etc. have been created, or demonstrations have been set up. Museums, exhibition halls, etc. for the development of modern red culture. Among these red existing cultural resources, many resources not only have a strong regional style, but also show them in vivid art form. For example, in the Xiangjiang Battle Monument Garden in Guangxi, there is the largest white granite relief in the country; Baise The Yuedong Guild Hall in the region is not only the revolutionary site of Deng Xiaoping's leadership of the Baise Uprising, but also an outstanding representative of the traditional wooden architecture of the South. 
In general, based on the existing advantages of local red resources, by exploring the artistic characteristics of these resources, local cultural resources can be transformed into artistic resources, and a group of outstanding artistic resources representatives are first introduced into the use of ideological and political classrooms of colleges and universities.

Secondly, play the leading role of local art colleges and establish a provincial art resource practice base and network platform. Because local art colleges have the natural advantages of the locality and professionalism, they have mastered the development of local art resources and possessed professional art knowledge. Therefore, they have certain guidance for the collection, selection and platform construction of regional art resources. Among them, the ideological and political teaching department and school of Marxism studies can actively call for the talent resources of the whole school. Firstly, the school will establish a platform for ideological and political art resources, and actively use the contemporary information ways such as the Internet to promote in the student groups. At the same time, we should introduce the local art resources into the ideological and political classrooms of local art academies firstly, accumulating practical experience with demonstration teaching, and then combining the practice and theory to summarize the application methods and teaching norms of local art resources in the ideological and political class, and prepare for further promotion to the whole region and the whole country.

The above points focus on the selection of local art resources and how to promote two issues across the country. It is recommended to take two steps in the practice of introducing it into the ideological and political teaching. Firstly, based on the local red culture, to play the leading role of local art in colleges and universities, integrating local resource advantages, taking the lead in introducing excellent local art resources in the ideological and political classrooms of the region, and then organizing cross-regional teaching and discussion activities to achieve regional exchanges and sharing of resources, further integrate the teaching achievements of local art resources in the ideological and political classrooms in various regions, and form a systematic and excellent curriculum to be promoted nationwide.

\section{Conclusion}

Generally speaking, "art" is not just a means of expression, but also an ideology. It reflects the development of society in the form of work, and combines with social activities to form both material and social. The form of "art resources". As a concrete manifestation of art resources, local art resources show the historical dynamics of politics, economy and culture of the region in terms of local art style. It not only represents the characteristics of regional culture, but also shows the creativity and vitality of indigenous people. An excellent and accessible cultural resource. Introducing local art resources into the teaching of ideological and political course in colleges and universities is not only the need for the further integration of art resources and ideological and political teaching, but also the need for the integration of local culture and Marxist theoretical education. The deepening of Marxist theoretical schooling will certainly have a good influence and promotion.

\section{References}

[1] For example, He Guangbiao, "On the Development and Utilization of Yunnan Tourism and National Culture and Art Resources” (National Art Research, 1996-06), Tan Ji, "International Computer Internet Art Resource Guide” (Fujian Art, 1997-08), Jiangning Activating Art Resources to Develop Cultural Industry__Discussing the Development and Utilization of Art Resources (Art 100, 2001-03), etc. These articles link "art resources" with economic and cultural activities such as tourism, internet, trade, etc. Emphasis is placed on the economic and social attributes of art resources.

[2] Mei Jianying, on the issue of local art style - a brief discussion on the characteristics of Shandong Zibo color porcelain, [J], decoration, 1980-03. 
[3] Huang Yongjian, local art and local art in the context of globalization. [J], Journal of Shenzhen University, 2012-09.

[4] Xu Hui, He Yuwen. Counting on Art Resources to Improve the Effectiveness of Ideological and Political Education [J]. Journal of Southwest University for Nationalities (Humanities and Social Sciences).2012.10:32-33

[5] Wu Xiaochun. Research on Teaching Innovation of Ideological and Political Theory Courses in Art Colleges-Based on the Ideological Attribute of Art[J]. Ideological Education Research.2016.05:92-95. 